\title{
THE ANATOMY OF SAKURAEOLIS
} ENOSIMENSIS (BABA, 1930), N. G. (=HERVIA CEYLONICA (?) ELIOT, 1913) (NUDIBRANCHIAEOLIDOIDEA)

\section{$\operatorname{AUTHOR}(\mathrm{S})$ :}

Baba, Kikutaro; Hamatani, Iwao

\section{CITATION:}

Baba, Kikutaro ... [et al]. THE ANATOMY OF SAKURAEOLIS ENOSIMENSIS (BABA, 1930), N. G. (=HERVIA CEYLONICA (?) ELIOT, 1913) (NUDIBRANCHIA-EOLIDOIDEA). PUBLICATIONS OF THE SETO MARINE BIOLOGICAL LABORATORY 1965, 13(2): 103-113

\section{ISSUE DATE:}

1965-08-30

URL:

http://hdl.handle.net/2433/175401

RIGHT: 
THE ANATOMY OF SAKURAEOLIS ENOSIMENSIS (BABA, 1930), N. G. (= HERVIA CEYLONICA (?) ELIOT, 1913) (NUDIBRANCHIA-EOLIDOIDEA)

\author{
KIKUTARO BABA and Iwao HAMATANI \\ Biological Laboratory, Osaka Gakugei University, Osaka
}

With Plates VIII-X

For the senior author it has been a serious problem to find out from the viewpoint of comparative anatomy the appropriate situation of the Japanese species of eolids, Hervia ceylonica (?) ELIOT, 1913, Cuthona (Hervia) japonica BABA, 1937=Rizzolia modesta BERGH, 1880 (see LeMChe, 1964, p. 57), C. (H.) emurai BABA, 1937 and $C$. (H.) inconspicua $\mathrm{B}_{\mathrm{ABA}}, 1938$, in the latest system of classification. All of them were included by MACNAE (1954, pp. 20-23; see also BABA, 1955, pp. 36, 56) in the genus Godiva MaCnaE, 1954 (cf. Lemche, 1964, pp. 56-57), and later transferred by MARCUS (1958, pp. 61-62; see also ABE, 1964, pp. 69-70) to Dondice MARcus, 1958. This affair of confusion, of which some critical mention was made by Edmunds (1964, p. 27) and Risso-Dominguez (1964, pp. 223-226) separately, depends largely upon the inefficiency of the original descriptions given to these species, and in a less degree upon the difficulty in recognizing the proper limit of each of the suggested genera to which species other than type might be allocated.

As the first report of the authors' re-examination studies of the given species, this paper is aimed to provide full accounts of the anatomy of Hervia ceylonica (?) ELIOT, 1913, the species which will be entitled as Sakuraeolis enosimensis (BABA, 1930), n.g., in the following text. Unfortunately Hervia ceylonica FARRAN, 1905 from the Gulf of Manaar is not satisfactorily known (cf. Farran, 1905, p. 331, pl. 1, figs. 1-5; O'Donoghue, 1932, p. 145 ; Satyamurti, 1952, pp. 250-251, pl. 34, figs. 1a-1e), and so it is set apart for revision of specimens from the type locality.

The main part of this paper was prepared by the senior author, and the junior author made possible efforts to get figures of the central nervous system of senior author's species.

Publ. Seto Mar. Biol. Lab., XIII (2), 103-113, $1965 . \quad$ (Article 5) 


\section{Sakuraeolis ${ }^{1)}$ BABA, n. g.}

Most closely related to Rizzolia or Dondice in the general features, but differentiated from them especially in the penis sheath which is provided with paired fleshy flaps and a stalked accessory penis gland on the inner wall. Vas deferens prostatic throughout. Penis tongue-shaped, muscular, and without an apical hook. The majority of the liver branches in the form of horseshoes, the largest horseshoes having $2(-3)$ rows of branchial papillae. Right mantle margin usually with cushions between liver horseshoes. Anus cleioproctic. Rhinophores smooth; foot-corners tentaculiform. Jaw-plates indented dorsally. Central radula tooth broadly horseshoe-shaped with several, rather strong lateral denticles.

Type: Hervia enosimensis $\mathrm{BABA}, 1930$.

Cuthona (Hervia) japonica BABA, 1937 is the second species ${ }^{2)}$ to be referred exactly to this new genus.

Sakuraeolis enosimensis (BABA, 1930)

\section{(Japanese name: Akaera-minoumiushi)}

Hervia ceylonica (?) Elot, 1913, p. 42.-Enoura, Suruga Bay.

Hervia enosimensis BABA, 1930, pp. 118-119, 124, pl. 4, fig. 2, text-figs. 1a-1c.--Enoshima, Sagami Bay.

Cuthona (Hervia) ceylonica BABA, 1935, pp. 354-356, pl. 7, fig. 3, text-fig. 16.--Mutsu Bay; BABA, 1937, p. 329 (list).

Cuthona (Hervia) enosimensis BABA, 1937, p. 329.

Hervia ceylonica BABA, 1933, p. 178.-Amakusa ; BABA, 1949, pp. 104-105, 178, text-figs. 138139 Sagami Bay; BABA, 1955, pp. 34, 55, pl. 20, figs. 54-56.-Sagami Bay; BABA, HAMATANI \& HISAI, 1956, p. 215, figs. 6a-6b, text-fig. 3B (spawning habits); INABA \& Hirota, 1958, p. 159, text-figs. 24-26 (chromosome number).

Godiva ceylonica BABA, 1955, pp. 36, 56 (generic name change).

Dondice ceylonica ABE, 1964, p. 69, pl. 34, fig. 119, text-fig. 28.-Toyama Bay and vicinity.

In Japanese waters this species is widely distributed on the Pacific coasts (Mutsu Bay ; Sagami Bay ; Suruga Bay; Shima ; Seto, Kii ; Osaka Bay ; Inland Sea of Seto; Saeki Bay; Amakusa) as well as on the Japan Sea side (Sado Is.; Toyama Bay and vicinity), and sometimes the animals appear on shores in considerable numbers for reproduction (cf. Baba, Hamatani \& Hisai, 1956, p. 215). At Tamano, Inland Sea of Seto, this species was found feeding on some thecate hydrozoans.

Observation was carried out perferably on live specimens collected by

1) 'Sakura' was adopted from the native name of Cherry in Japan.

2) The closest affinity between enosimensis and japonica was already suggested by INABA \& HiRota (1958) on the basis of their chromosome survey in these two species. 
the authors or by their friends from various stations. For the examination of internal organs, eleven specimens listed below were prepared in serial sections stained by DeLAFiELD's haematoxylin and eosin.

Sp. No. 1. Loc.: Sugashima, Shima. Date: Apr. 7, 1962. (H. S.)

Sp. Nos. 2-6. Loc.: Tannowa, Osaka Bay. Date: Mar. 9, 1951. (H. S.)

Sp. No. 7. Loc. : Mukaishima, Inland Sea of Seto. Date: Mar. 28, 1963. (H. S.)

Sp. No. 8. Loc.: Tannowa, Osaka Bay. Date: Mar. 9, 1951. (L. S.)

Sp. Nos. 9-10. Loc.: Tannowa, Osaka Bay. Date: Mar. 9, 1951. (T. S.)

Sp. No. 11. Loc.: Tamano, Inland Sea of Seto. Date: Apr. 22, 1962. (T. S.)

Of these, Sp. No. 1 was juvenile, and the rest were fully matured. Sp. Nos. 2, 5, 6 and 7 showed each a protruded penis.

Externals: The general body-form and colours are roughly as repeatedly reported before. The total length (Code Ac) is usually $20-30 \mathrm{~mm}$, and the maximum length reaches to $45 \mathrm{~mm}$. The cephalic tentacles are exceedingly slender. The rhinophores are shorter, and smooth in fresh. The foot-corners are tentaculiform. The tail is long and tapering behind. The branchial groups are usually in $6-8$ pairs. The right liver branch (and the left partner) forms a horseshoe. The left posterior liver branches are mostly horseshoeshaped. Apparently these horseshoes are more evident than in Rizzolia and Favorinus, and they show marked tendency to become larger with the growth of the animal. The following is an example of branchial formula taken from one of the largest specimens (Ac $45 \mathrm{~mm})^{1)}$, from the right and left sides: I (63-66), II (57-56), III (30-32), IV (16-23), V (18-14), VI (14-14), VII-VIII (a few papillae in simple rows). The papillae themselves are elongated fusiform when fully extended, easily falling off, and rather thickly set in $2(-3)$ rows on each of the largest horseshoes. The genital orifice lies immediately below the fore-leg of the second right horseshoe, and this situation marks the species fairly well (in S. japonica the genital orifice is just halfway between the first and second horseshoes, and in Rizzolia it is below the first horseshoe on the right side). The anus and nephroproct are as usual in the Cleioprocta. In this species there are always a series of fleshy cushions on the right margin of the mantle (in S. japonica these structures are sometimes marked, and sometimes obsolete), each one lying in between the horseshoes of the left posterior liver. The cushion in life is whitish, and contains a thick cluster of eosinophileous compound glands below the cliated epithelium.

Variation in tones of the body-colour is remarkable according to different specimens. The general integument is of a translucent yellowish. Often

1) A branchial formula counted on the right side in one of the smaller specimens (Ac $15 \mathrm{~mm}$ ) may be shown thus: I (25), II (23), III (22), IV (15), V (10), VI (5), VII (3). Those from the first to the fourth are horseshoe-shaped. The papillae are set in double rows on the largest horseshoes. 
there are individuals with a thick pigmentation of orange-yellow on the head (to the lower halves of the cephalic structures), back and branchial papillae, and the whole body of them may appear to be intensively orange-red. The vein (=liver-diverticulum) of the papillae is from ashy yellow to orangeyellow, and sometimes each of these shades acquires an orange-red hue towards the distal end of the vein. The cephalic tentacles have each a longitudinal streak of opaque white. The rhinophores above are opaque white. The median line of the tail is opaque white. There are scattered opaque white spots over the head, back, sides and papillae. The papillae may sometimes be seen capped with opaque white. The sole is colourless.

Internals: The main features of the jaw-plates and radula are also as described previously. The jaw-plates, horny yellow in fresh, have each a dorsal indentation. The jaw-edge bears a series of 35-40 regular denticles. The fresh ribbon of the radula is colourless, and shows a formula $18 \times 0.1 .0$ on the specimen dissected for drawing. The teeth are broadly horseshoeshaped, bearing 3-5, rather strong denticles on either side of a produced median cusp. The number of lateral denticles may range between 3-7 according to specimens. The liver system in Sakuraeolis does not differ materially from that of Rizzolia and Favorinus except for the especial development in the formation of horseshoes. The digestive tract proper in S. enosimensis is ciliated on the inner surface. The salivary glands are long and band-like. The stomach has no accessory blind sac. The intestine is comparatively long, and always makes up a loop at its origin from the stomach. It bears an inner longitudinal ridge as usual. The liver-diverticulum within each of the branchial papillae is a simple tube. Distally the diverticulum passes in to the cnidosac through a slender canal. In fresh, the cnidocysts contain colourless homogeneous droplets. The nematocysts taken in the cnidocysts were shown by experiments on starved animals to be well preserved for a considerably long lapse of time.

The freshly isolated liver cells assume different facies: (1) some are filled with mostly small, ashy yellow ferment granules; and (2) some are packed with coarse, colourless ferment granules; and (3) others are densely charged with refringent, yellow excretory granules. Distinction in colour between the types (1) and (2) may not be absolute though the shade of ashy yellow did not be affected by the starvation of the experimented animals. In both types, the ferment granules are easily destroyed into finer granulations by a fixing fluid. The yellow excretory granules of the type (3) do not undergo destruction by a fixative; on mounted sections they are seen to collect together in a mass of yellow concretions that is enclosed within a spacious vacuole (cf. BABA \& HamATANI, 1964, p. 159-Favorinus; BABA, 1964, p. 291-Rizzolia). Actually the refringent yellow granules cited above con- 
stitute the main elements of the faeces in nature. The faeces, dirty yellow or dirty yellowish brown and short rod-like in appearance, may sometimes contain nematocysts and radula teeth rejected through the digestive tract. The liver cell type (3) of this species reminds us of the formation of a yellow vacuole in Cuthona futairo (cf. BABA, 1963, p. 113).

The composition of the central nervous system and the distribution of nerves from it are nearly as in Aeolidia papillosa (cf. Russeli, 1929, pp. 210218). There are more than ten statoliths in each of the statocysts. In the adult the inner wall of the reno-pericardial canal is thickly folded longitudinally. The main canal of the kidney sends off extremely complicated branches on either side of its entire length.

In Godiva quadricolor the penis is rather 'almond-shaped' with an apical hook and without an accessory penis gland. The penis of Dondice occidentalis is cone-like, unarmed, and includes a prostate pouch and an accessory penis gland within it. In $S$. enosimensis the penis proper in the contracted state takes the form of a tongue at the apex of which opens a pore of vas deferens. There is no apical hook. The penis proper is highly muscular, and there are interlaced muscle fibres below the surface epithelium. The interior of the penis proper is lacunose. Almost the whole length of the vas deferens is prostatic nearly as in Godiva (in Dondice this is not prostatic). But in $S$. enosimensis an unusual specialization takes place in the structure (and function) of the penis sheath. This sheath is exceedingly spacious, and has a rich supply of muscle fibres on the outer wall. The contracted penis proper occupies the bottom of the sheath. On the inner wall of the sheath there are two fleshy flaps (an upper and a lower) and a stalked accessory penis gland which is dissimilar to the gland of the same name in Dondice occidentalis but presumably similar to that in Echinopsole fulvus (cf. MACNAE, 1954, p. 28). The accessory penis gland in Rizzolia lineata is situated on the inner wall of the penis sac, but its shape and structure are preculiar to this form (cf. BABA, 1964, p. 291). A penis sheath with flaps and stalked accessory penis gland occurs also in S. japonica.

For the act of copulation the penis sheath is everted and the stalked accessory penis gland comes to rise up from the hood which is presumably formed by the union of the dilated flaps. The penis proper, supported by the everted sheath, is protrusible greatly. When fully extended it is soft and vermiform, and may bend freely. The stalked accessory penis gland is swollen at the distal end where there are an aggregation of compound, eosinophileous, glands. The glandular part appears to be opaque white in a fresh material. Pairing action preceded by fighting approaches (cf. RissoDominguez, 1962, p. 149) was once briefly observed between two matured specimens kept alive in a laboratory aquarium (Tamano, Inland Sea of Seto, 
May 1, 1957; pairing commenced in the morning at $7.50 \mathrm{hr}$ and ended at $8.30 \mathrm{hr}$ ). The everted hood parts were applied to each other, and they helped the interlock of the extruded penes of the two individuals.

The ampulla is slightly coiled against the thick coiling of it in Godiva. The spermatheca is spoon-shaped. The male and female orifices are united, but sometimes they may appear to be separated by a protruded flap of the integument between the two orifices. In general, the composition of the accessory genital complex in $S$. enosimensis is more complicated than in Rizzolia and Favorinus. In matured specimens there are a considerable number of testes, each accompanied by several ovarian follicles, within the haemocoele.

Remarks: In spite of the conjecture promoted by Risso-Dominguez (1964, pp. 223-226), Rizzolia Bergh, 1880 (p. 4) can hardly be synonymized with Rizzolia Trinchese, 1877. The scope of the latter genus is to be sharply confined to the type peregrina GMELIN, 1791 (=Facelina veranyana BERGH, 1874, after RissoDominguez, 1964, p. 223) and its closest allies, if they could be determined as such. Virtually enosimensis and japonica differ from peregrina in the external configuration (development of the liver horseshoes, situation of the genital orifices), in the denticulation of the radula teeth, and presumably in the structure of the male genital system, and so they are excluded from Rizzolia here.

Also it seems better to recognize strictly the limit of each of the two genera, Godiva and Dondice, on the basis of their respective types (cf. EDmunds, 1964, pp. 26-27).

Additional specimens of Cuthona (Hervia) inconspicua were gathered from various parts of our country including the type locality, and some of them were disposed for dissection. Now it was made clear that inconspicua shows a high degree of resemblance to the type of Godiva, namely Hervia quadricolor BARNARD, 1927, from S. Africa, in the detail of colours (especially in the banded colouring of the branchial papillae), in the development of the liver horseshoes, in the situation of the genital orifices just below the fore-leg of the first right horseshoe, in the shape and denticulation of the central teeth, in the long and convoluted ampulla, in the short and thick vas deferens which is prostatic nearly throughout, and in the muscular penis not accompanied by an accessory penis gland. But there is no apical hook on the penis of inconspicua. Following to the presentday manner of classification, to which some objection may arise later, to separate Cuthona from Trinchesia (=Catriona) by the absence of a penis stylet in the former, creation of a new genus is suggested as below:

Setoeolis BABA, n. $\mathrm{g}$.

Type: Cuthona (Hervia) inconspicua BABA, 1938. 
As for Cuthona (Hervia) emurai, supplementary observation was made possible on a collection of new material mainly from the Japan Sea district covering the vicinity of the type locality. This species is highly distinctive in its colours. The liver horseshoes are well-developed as in quadricolor and inconspicua, and those of the left posterior liver are markedly close together. The genital orifices open just below the hind leg of the first right horseshoe. The jaw-plates are without a dorsal indentation as in inconspicua. The median cusp of each of the central teeth bears always a series of serrulations on the ventral side in the median line. The penis is elongated conical, muscular, and without an apical hook as in the case of Setoeolis. An accessory penis gland is absent here also. The peculiarity of this penis lies in the presence of a paddle-like wing which is found applied to the proximal half of the penis on its upper and lateral side. The paddle itself is not glandular, and the head of the paddle is covered with minute warts. The intermediate zone of the length of the penis proper is also studded with similar warts on the surface. The distal half of the vas deferens is prostatic, and more proximally it is muscular. The ampulla is fairly long and coiled. The spermatheca in its distal half is more or less convoluted. Laying stress on such a penis as that which has no hook apically but which has a paddle-like wing proximally, a new generic name is proposed for emurai as below:

Shinanoeolis ${ }^{1>}$ BABA, n. g.

Type: Cuthona (Hervia) emurai BABA, 1937.

Here discussions and suggestions were made exclusively in favour of our species from Japan. Full accounts on the anatomy of Sakuraeolis japonica (BABA), Setoeolis inconspicua (BABA) and Shinanoeolis emurai (BABA) will be given later in a series of papers.

\section{REFERENCES}

ABE, T. 1964. Opisthobranchia of Toyama Bay and adjacent waters. Hokuryu-kan, Tokyo.

BABA, K. 1930. Studies on Japanese nudibranchs (3). Venus, vol. 2, no. 3.

1933. Preliminary note on the Nudibranchia collected in the vicinity of the Amakusa

Marine Biological Laboratory. Annot. Zool. Japon., vol. 14, no. 1.

1935. Report of the biological survey of Mutsu Bay. 27. Nudibranchia of Mutsu

Bay. Sci. Rep. Tôhoku Imp. Univ., ser. 4, Biol., vol. 10, no. 2.

1937. Opisthobranchia of Japan (II). Journ. Dept. Agric. Kyâshâ Imp. Univ., vol. 5, no. 7 .

1938. Opisthobranchia of Kii, Middle Japan. Journ. Dept. Agric. Kyûshû Imp. Univ., vol. 6 , no. 1 .

1949. Opisthobranchia of Sagami Bay. Iwanami Shoten, Tokyo.

1955. Opisthobranchia of Sagami Bay, Supplement. Iwanami Shoten, Tokyo.

1) Shinano was derived from the old province name of the type locality of emurai. 
BABA, K. 1963. The anatomy of Cuthona futairo n. sp. (=C. bicolor of BABA, 1933) (Nudibranchia-Eolidoidea). Publ. Seto Mar. Biol. Lab., vol. 11, no. 1.

- 1964. The anatomy of Rizzolia lineata (Eliot) (Nudibranchia-Eolidoidea). Publ. Seto Mar. Biol. Lab., vol. 12, no. 4.

BABA, K. \& HAMATANI, I. 1964. The anatomy of Favorinus japonicus BABA (NudibranchiaEolidoidea). Publ. Seto Mar. Biol. Lab., vol. 12, no. 2.

Baba, K., Hamatani, I. \& Hisal, K. 1956. Observations on the spawning habits of some of the Japanese Opisthobranchia (II). Publ. Seto Mar. Biol. Lab., vol. 5, no. 2.

BARNARD, K. H. 1927. South African nudibranch Mollusca, with descriptions of new species, and a note on some specimens from Tristan d'Acunha. Ann. S. Afr. Mus., vol. 25, pt. 1.

BERGH, R. 1874. Beiträge zur Kenntniss der Aeolidiaden. II. Verh. k. k. zool.-bot. Gesell. Wien, Bd. 24.

1880. Beiträge zur Kenntniss der japanischen Nudibranchien. I. Verh. k. k. zool.-bot. Gesell. Wien, Bd. 30.

1882. Beiträge zur Kenntniss der Aeolidiaden. VII. Verh. k. k. zool.-bot. Gesell. Wien, Bd. 32.

Edmunds, M. 1964. Eolid Mollusca from Jamaica, with descriptions of two new genera and three new species. Bull. Mar. Sci. Gulf and Carib., vol. 14, no. 1.

Eliot, C. 1913. Japanese nudibranchs. Journ. Coll. Sci. Imp. Univ. Tokyo, vol. 35, art. 1.

FARran, G. P. 1905. Report on the opisthobranchiate Mollusca. Rep. Pearl Oyster Fish. Gulf of Manaar. Suppl. Rep. Mar. Biol. Ceylon, pt. 3.

InABA, A. \& HirotA, R. 1958. Chromosome survey in ten species of nudibranchs (Gastropoda, Mollusca). Japan. Journ. Zool., vol. 12, no. 2.

LeMCHE, H. 1964. Godiva MACNAE, 1954 (Gastropoda) : proposed addition to the Official List as a replacement for Hervia Auctt. (nec. BERGH, 1871). Z. N. (S.) 1107. Bull. zool. Nomencl., vol. 21 , pt. 6 .

Macnae, W. 1954. On some eolidacean nudibranchiate molluscs from South Africa. Ann. Natal Mus., vol. 13, pt. 1.

MARcus, Er. 1958. On western Atlantic opisthobranchiate gastropods. Amer. Mus. Novitates, no. 1906.

O'Donoghue, C. H. 1932. Notes on Nudibranchiata from southern India. Proc. Malac. Soc. London, vol. 20 , pt. 3.

Portmann, A. \& SANDMEIER, E. 1960. Dondice banyulensis, sp. nov. un eolidien nouveau de la Méditerranée. Rev. suisse de Zool., tom. 67, no. 7.

Risso-Dominguez, C. J. 1962. Notes on the Facelinacea. I. Introduction. Ann. Mus. Civ. Stor. Nat. Genova, vol. 73 .

1964. Notes on the Facelinacea. II. On the systematic position of Hervia serrata BABA, 1949 and Favorinus horridus MACNAE, 1954. Beaufortia, vol. 10, no. 128.

RUSSELL, L. 1929. The comparative morphology of the elysioid and aeolidioid types of the molluscan nervous system, and its bearing on the relationships of the ascoglossan nudibranchs. Proc. Zool. Soc. London, pt. 2.

Satyamurti, S. T. 1952. The Mollusca of Krusadai Island (in the Gulf of Manaar). I. Amphineura and Gastropoda. Bull. Madras Gov. Mus., n. s., Nat. Hist. Sect., vol. 1, no. 2, pt. 6 . 


\title{
EXPLANATION OF PLATES VIII-X
}

\author{
Sakuraeolis enosimensis
}

\section{Plate VIII}

Fig. 1. Entire animal in life, length (Code Ac) $20 \mathrm{~mm}$. Material: Tamano, Inland Sea of Seto (Apr. 30, 1957). Showing an individual of paler colouration.

Fig. 2. A detached branchial papilla in fresh. Material : Sugashima, Shima (Apr. 7, 1962). Here the diverticulum in the papilla is dark yellow below, showing a reddish hue above with the addition of orange-red liver cells.

Fig. 3. Longitudinal section of a branchial papilla ( $\times 75)$. Material: Sp. No. 1 . a. cnidosac, b. canal, c. liver-diverticulum, d. septum and a sphincter muscle ring.

Fig. 4. A row of cnidocysts $(\times 270)$. Material: Sp. No. 1. a. interstitial cell, b. vacuolated cytoplasm of cnidocysts.

Fig. 5. Isolated cnidocysts in fresh $(\times 270)$. Material: Mukaishima, Inland Sea of Seto (Mar. 28, 1963). a. nucleus, b. colourless droplets included within cytoplasm.

Figs. 6-9. Material: Mukaishima (Mar. 28, 1963).

Fig. 6. Pharynx from above. a. left jaw-plate, b. right jaw-plate.

Fig. 7. Right jaw-plate from outside $(\times 13)$. Denticulations on jaw-edge 35-40.

Fig. 8. Pharynx from right side. a. buccal ganglion, b. right jaw-plate, c. radula ribbon (formula $18 \times 0.1 .0$ ), d. salivary gland.

Fig. 9. A central tooth $(\times 70)$. Denticles $3-5$.

Fig. 10. Digestive system in the body, diagrammatic. Main material: Sp. No. 3. a. right liver, b. reno-pericardial canal, c. nephroproct, d. genital orifice, e. anus, f. cushions, g. left posterior liver, h. cross section of rectum, i. cross section of intestine, j. left anterior liver, k. salivary gland. This figure shows also the development of liver horseshoes in about $25 \mathrm{~mm}$ long specimen. Its branchial formula taken from the right side is: I (30), II (30), III (20), IV (20), V (10), VI-VIII (a few papillae in simple rows). 


\section{Plate IX}

Fig. 1. Cross section of liver-diverticulum within a branchial papilla $(\times 185)$. Material : Sp. No. 11. a. liver cells, b. vacuoles each enclosing a mass of yellow concretions.

Fig. 2. Freshly isolated liver cells $(\times 400)$. Material: Mukaishima (Mar. 28, 1963). a. liver cell with ashy yellow ferment granules, b. liver cell with colourless ferment granules, c. liver cells each with refringent yellow excretory granules.

Fig. 3. A piece of newly emitted faeces formed of refringent yellow excretory granules and nematocysts. Material: Mukaishima (Apr. 9, 1963).

Fig. 4. Cross section of the body on level of the anus $(\times 10)$. Material: Sp. No. 9. a. main canal of kidney with its lateral branches (d) on either side, b. lateral branches of the left posterior liver $(g)$, the formers passing into the second (right and left) horseshoes, c. anus, e. cushion, f. fine branches about to join with the common hermaphrodite duct (h).

Fig. 5. Cushion in vertical section $(\times 45)$. Material: Sp. No. 9. a. ciliated epithelium, b. compound glands.

Fig. 6. Reno-pericardial canal in vertical section $(\times 20)$. Material: Sp. No. 9. a. ventricle, b. kidney, c. pericardium.

Fig. 7. Part of body in horizontal section $(\times 30)$. Material: Sp. No. 1. a. intestine, b. nephroproct, c. papillae of the second right horseshoe, d. kidney, e. stomach.

Figs. 8-9. Central nervous system from above (fig. 8) and from below (fig. 9). Material: Tamano (Apr. 28, 1962). Denomination of ganglia and nerves mainly after Russell, 1929.

CG. Cerebro-pleural ganglion, PG. pedal ganglion, BG. buccal ganglion (=stomato-gastric ganglion), GG. Gastro-oesophageal ganglion, RG. rhinophorial ganglion.

c. eye, d. optic ganglion, e. salivary duct, f. statocyst, g. gastrooesophageal nerve, $h$. pedal commissure, i. parapedal commissure, j. pleuro-visceral connective, k. cerebro-buccal connective.

n. $1 \sim$ n. 8 . cerebro-pleural nerves : n. 1 . rhinophorial nerve; n. 2. nerve to mouth part (a), head integument (b) and cephalic tentacle $\left(b^{\prime}\right) ; n .3$. nerve to mouth part (a) and cephalic tentacle (b); n. 4. nerve to buccal retractor, etc.; n. 6 . nerve to lateral integument and branchial papillae; n. 7. nerve to lateral body wall, branchial papillae, etc.; n. 8 . posterior pallial nerve. n. $9 \sim$ n. 10. pedal nerves: n. 9 anterior pedal nerve; n. 10. middle pedal nerve (a) and posterior pedal nerve (b). 


\section{Plate X}

Fig. 1. An animal creeping upside-down on the surface film of the aquarium water. Material: Tannowa, Osaka Bay (Mar. 19, 1951). a. stalked accessory penis gland, b. hood, c. penis proper, d. egg-string appearing from the female orifice.

Fig. 2. Genital system in the body, diagrammatic. Main material: Sp. No. 2. a. protruded penis proper, b. female orifice.

Fig. 3. Different views of the male copulatory organ in fresh, from above. Material: Mukaishima (Mar. 28, 1963). a. protruded penis proper, b. stalked accessory penis gland, c. inflated hood, d. everted penis sheath.

Fig. 4. Distal end of the stalked accessory penis gland in vertical section $(\times 30)$. Material : Sp. No. 2. a. compound glands.

Fig. 5. Genital organs from above, diagrammatic $(\times 7)$. Main material: Sp. No. 3. a. contracted penis proper, b. upper flap, c. accessory penis gland situated below the upper flap, d. penis sheath, e. common genital orifice, f. outer oviduct, $g$. inner oviduct $(?=$ fertilization chamber), h. area of gland A (?=albumen gland), i. area of gland B $(?=$ mucous gland $), j$. vagina, $k$. spermatheca, 1 . hermaphrodite duct, m. ampulla, n. area of gland $\mathrm{C}(?=$ membrane gland), o. lower flap, p. postatic vas deferens. The gland A communicates with the gland $B$ on one hand, and opens into the outer oviduct on the other. The glands $\mathrm{B}$ and $\mathrm{C}$ are completely fused together.

Fig. 6. Cross section of the body on level of the common genital orifice $(\times 10)$. Material: Sp. No. 9. a. pericardial prominence including a ventricle, b. stalked accessory penis gland, c. upper flap, d. lateral branches sent off from the main canal (o) of kidney, e. penis sheath with outer muscular wall, f. lower flap, $g$. male orifice, h. outer oviduct leading to female orifice, $i$. origin of vas deferens from ampulla, $j$. area of gland $\mathrm{B}(?=$ mucous gland $), \mathrm{k}$. area of gland $\mathrm{C}(?=$ membrane gland $)$, 1. prostatic vas deferens to pass into penis proper, $m$. left posterior liver, $\mathbf{n}$. looped part of intestine.

Fig. 7. Cross section of the penis sheath $(\times 7)$. Material: Sp. No. 9. a. contracted penis proper, b. upper flap, c. lower flap, d. prostatic vas deferens. 
Publ. Seto Mar. Biol. Lab., XIII (2), 1965.

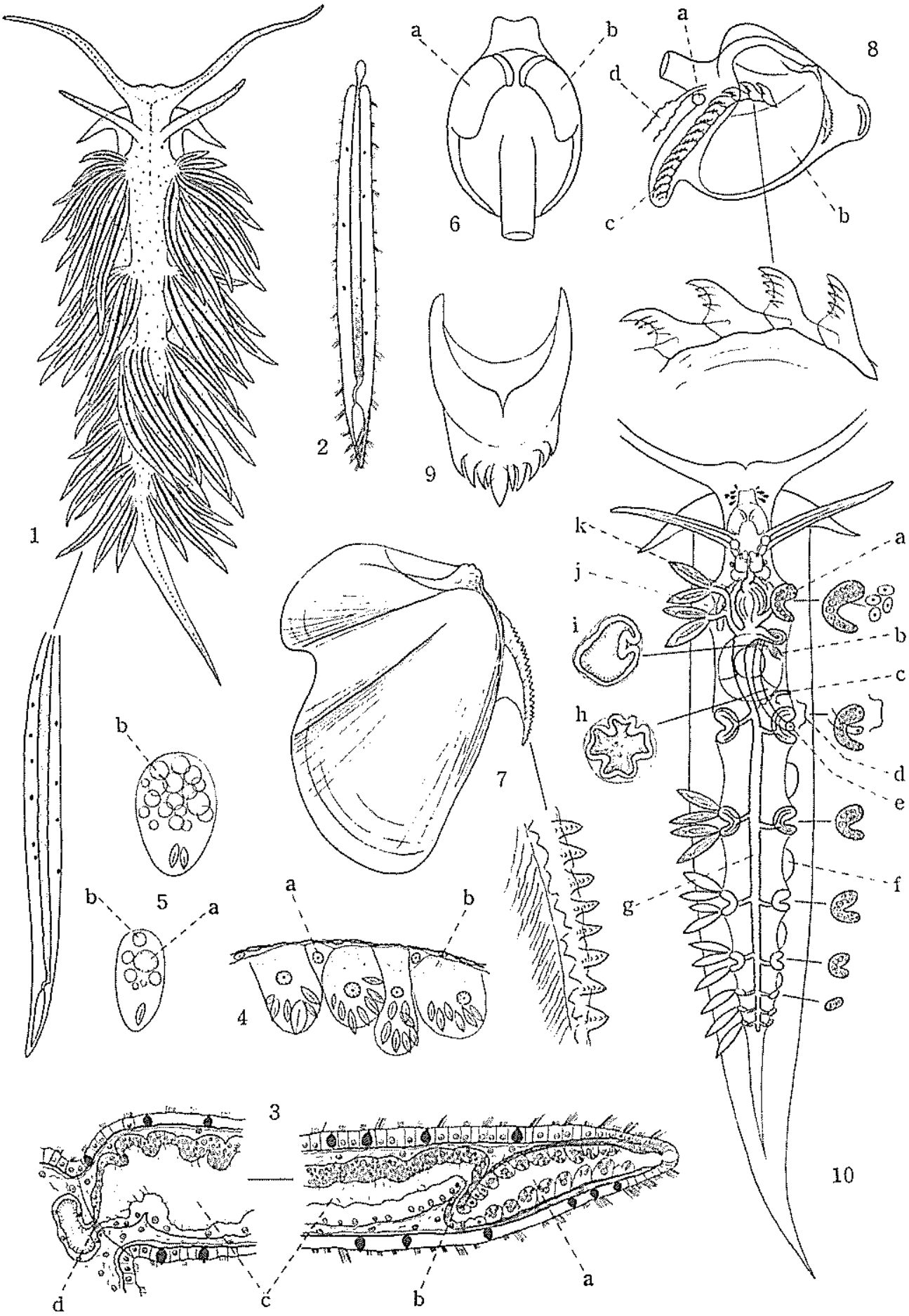

K. Baba \& I. Hamatani: Anatomy of Sakuraeolis enosimensis. 
Publ. Seto Mar. Biol. Lab., XIII (2), 1965.

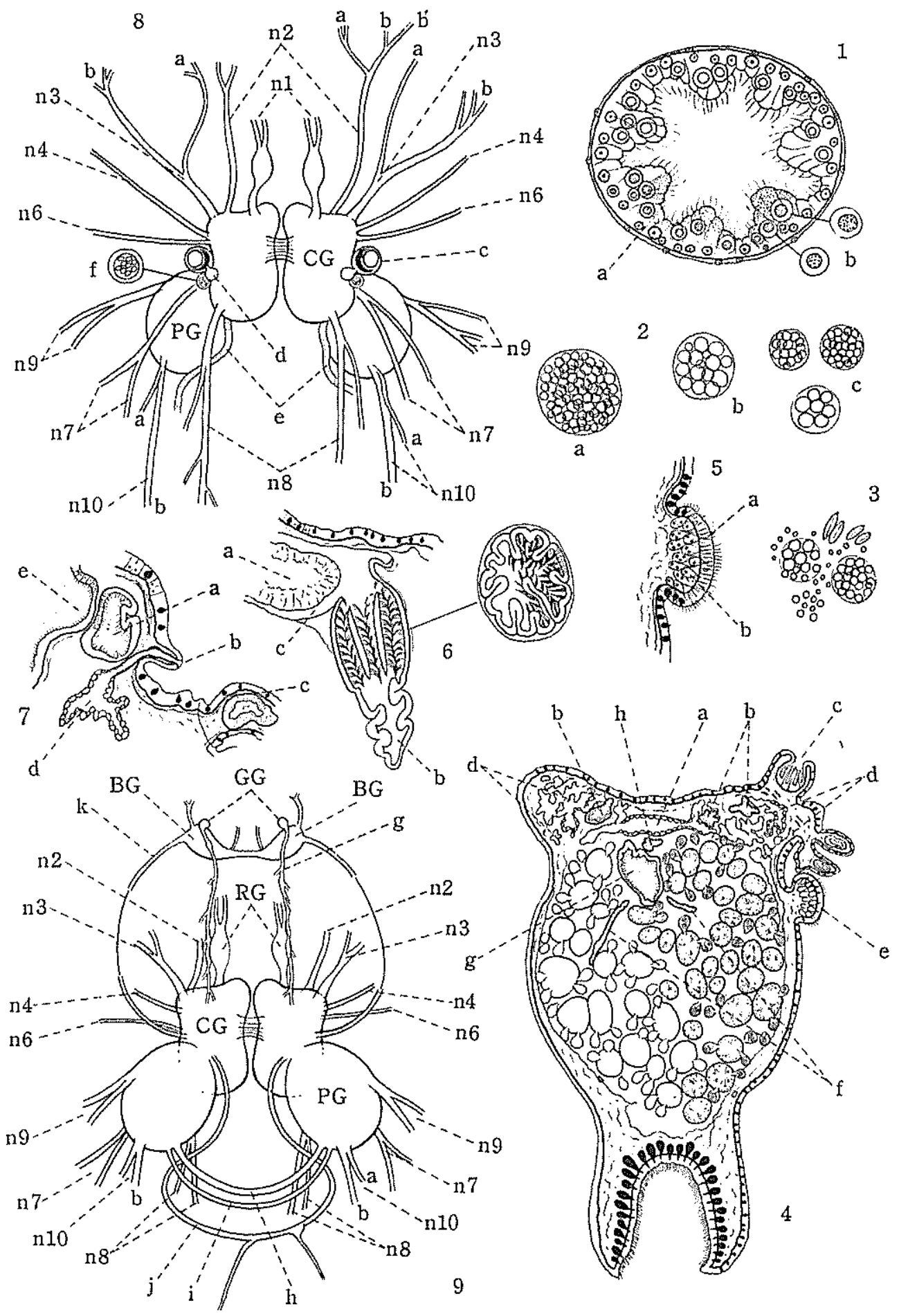

K. Baba \& I. Hamatani: Anatomy of Sakuraeolis enosimensis. 
Publ. Seto Mar. Biol. Lab., XIII (2), 1965.
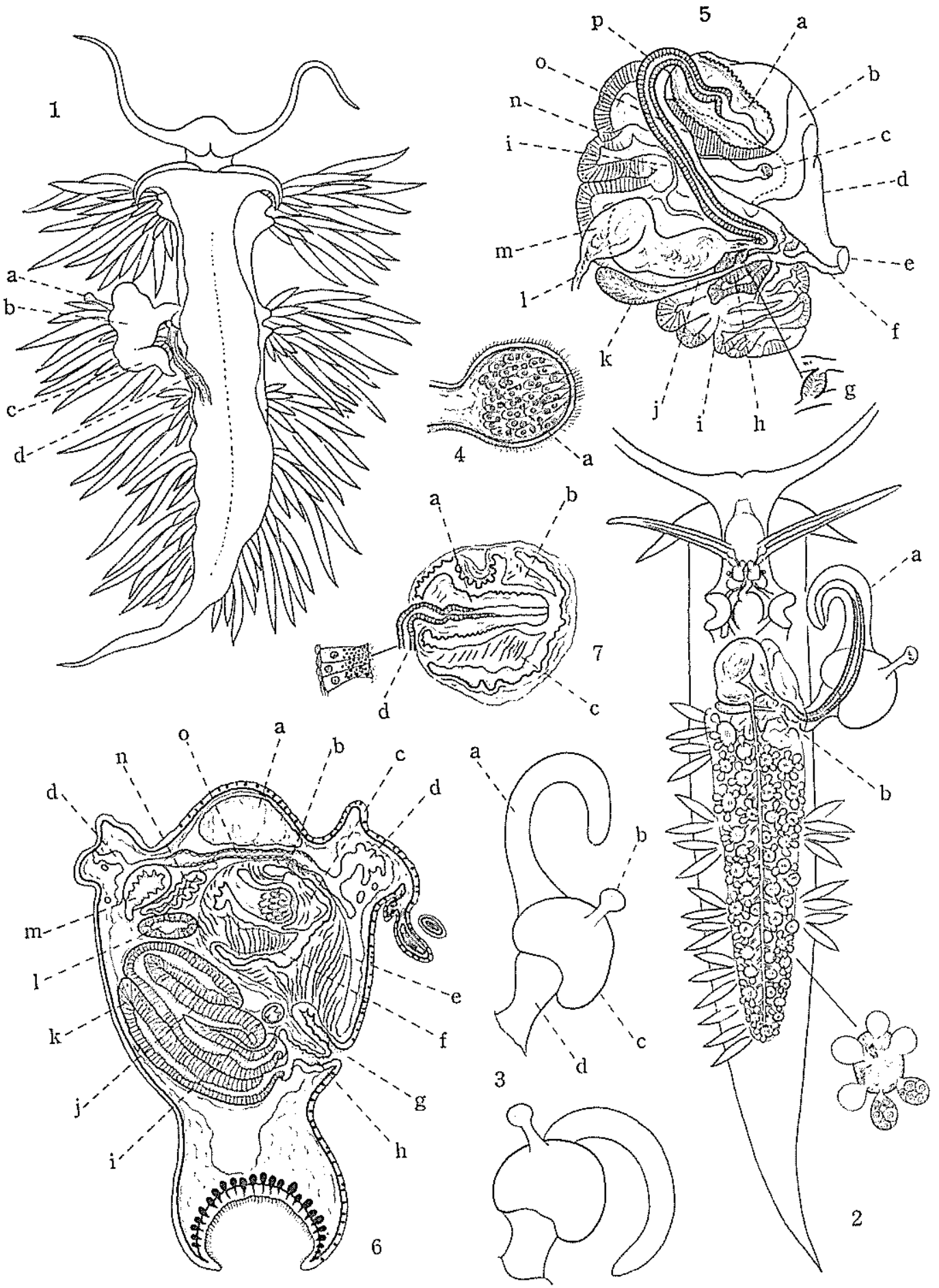

K. Baba \& I. Hamatani: Anatomy of Sakuraeolis enosimensis. 